nant à diverses populations, en Ghana, notamment. Les enquêtes que nous avons menées en 1956 ont fait apparaître que ces voyages étaient en réalité des pèlerinages, directement associés aux représentations qui intéressent les populations de l'Afrique de l'Ouest. Ces représentations constituent une structure socio-mythique internationale de ces populations, que nous avons publiée dernièrement ( $c f$. G. Dieterlen, 'Mythe et Organisation sociale au Soudan Français ', Journal de la Societé des Africanistes, tome xxv, r959). Les renseignements recueillis auprès de personnalités kéita du Mandé (notamment à Bamako) d'une part, comme auprès de personnalités dogon (région de Sanga) d'autre part, sont absolument concordantes concernant les buts de ces voyages.

En effet, l'objet principal des pèlerinages est un sanctuaire, situé dans la ville de Koumassi, comparable à celui du Mandé et qui serait l'objet d'un rite de réfection, exécuté sept mois après la cérémonie septennale de Kangaba, cérémonie à laquelle nous avons assisté en 1954 (voir l'article cité plus haut).

Ces déplacements, dont les bases sont religieuses, offrent un double aspect. Le pèlerinage était effectué autrefois :

$1^{\circ}$. par les prêtres totémiques qui devaient, avant leur intronisation, se rendre au sanctuaire de Koumassi - lequel est associé aux 'partages' des totems entre les 'familles ' primitives qui se sont développées et constituent actuellement des 'populations'.

$2^{\circ}$. par tout individu désireux de se marier qui devait rapporter des cauris, acquis par son travail, et destinés au premier ' don de mariage ' remis aux futurs beaux-parents, ainsi qu'un pagne spécial pour la fiancée.

De plus, le voyage et le travail fait pendant le séjour dans la ville, qui procuraient essentiellement à l'intéressé les cauris utilisés pour le mariage, étaient associés au commerce et à son développement. 'Faire le pèlerinage apportait la richesse et l'abondance dans la famille du pèlerin.' Koumassi paraît avoir été, pour l'Africain de l'Ouest, le lieu des 'échanges ', le 'grand marché', ce terme devant être pris dans un sens à la fois économique, social et culturel. Le travail effectué, mercenaire ou commercial, ne modifiait en rien le statut du pèlerin, qui retrouvait son rang dans sa famille et son clan, et bénéficiait de plus d'une certaine considération due au caractère rituel de son déplacement. Nous signalons que, lorsque le voyageur soudanais actuel rapporte de l'argent, des vêtements, ou des biens acquis par le travail effectué dans la ville, ce fait est encore directement associé aux représentations concernant la région de Koumassi.

Des renseignements sur la fréquence des voyages en Ghana nous ont également été communiqués récemment en ce qui concerne les Songhay du nord de la boucle du Niger, et pour les Peul du Macina. Ces faits nous paraissent à rapprocher d'observations rapportées par nombre d'auteurs dans des régions diverses. Voir notamment l'article sur les migrations saisonnières actuelles (destinées à procurer l'argent de l'impôt et du mariage) publié par A. H. M. Kirk-Greene, "Tax and Travel among the Hill-tribes of Northern Adamawa', Africa, xxvi. 4, p. 369 .

Communication de G. Dieterlen

\title{
West Africa and the Future
}

A sHORT study course was held at the School of Oriental and African Studies, University of London, in January 1957, on present problems and future developments in West Africa. At the opening session the ethnic and cultural groupings of the peoples of West Africa were discussed by Dr. J. Berry and a sketch of the historical background of the British West African territories was given by Mr. D. H. Jones, both members of the staff of the S.O.A.S. The second day was devoted to the consideration of political trends in French West Africa (Mr. T. Hodgkin) and British West Africa (Mr. David Williams) and to a discussion of social development (Dr. Margaret Read). Speakers on the third day dealt with questions of law 
and administration (Dr. Allott), agriculture (Mr. Silk), music (The Rev. A. M. Jones), and trade unions (Mr. W. Hood). The last day of the course was devoted to a consideration of various aspects of investment and technical aid, when papers were read by Mr. M. T. Mbu; Commissioner for Nigeria in the United Kingdom, Mr. A. D. Knox, and Dr. E. Hallett.

\section{The Garessa Museum, Mogadishu}

THE Garessa, now the national museum of Somalia, was opened in 1934 as the museum for what was then the Italian colony; it is housed in a magnificent fort built in the second half of the nineteenth century by the Sultan of Zanzibar as the seat of his government in Somalia. The museum possesses a wide variety of collections and includes a reading-room and an extensive modern library which contains many of the more important works on Somali ethnography and sociology, a fairly wide selection of publications on the former Italian African colonies and on Africa in general, as well as books of a more general nature.

Besides geological, zoological, numismatic, and other important collections, the Garessa contains possibly the finest collection of objects of ethnographic interest illustrating Somali culture. These include examples from the pre-Somali Negro riverain peoples of Somalia and from the other non-Somali minority communities. A valuable collection of historical manuscripts and documents includes many of the treaties and agreements made by local chiefs with the early Italian colonizers. There is also a considerable body of Arabic manuscripts, some religious works by Somali sheikhs, and a mass of correspondence between famous Somali personalities and the early Italian Administration. All these are of considerable interest not only for the local history of Mogadishu and the other ancient cities of southern Somalia, Merca, Brava, and Kismayu, but also for the general history of the East African coast. The interior courtyard of the Garessa is adorned with inscriptions from the old mosques of southern Somalia (mainly Mogadishu) some of which date from the eighth century, one being in Cufic characters. While it is true that many of the historical items in the museum have already been drawn upon in publications, mainly by Italian scholars, the museum still has much as yet unexploited material to offer to various branches of scholarship. It certainly deserves to be more widely known and visited. Although it is now out of date, some idea of the richness of the collections may be gathered from the 1934 catalogue (Museo della Garessa, Catalogo, Mogadishu, 1934, pp. 177, 109 Pp. illus.). A new catalogue and a rearrangement of the collections are in progress under the Garessa's enthusiastic new Director, Dr. S. Appolonio. The museum is also fortunate in having on its staff Yaasiin Ismaan Kenadiid, the son of Ismaan Yuusuf, inventor of the well-known 'Somali writing' (or Ismaaniya), an acknowledged authority on Somali folk-literature who has been trained in phonetics in Italy.

A recent venture is the publication of the bi-monthly periodical Somalia d'Oggi, edited from the museum, of which the first two numbers have now appeared. It is not a technical journal for specialists and is naturally largely devoted to the discussion of developments in the nascent state of Somalia and the surrounding territories. It does, however, devote some space to ethnographic and historical subjects. The second number, for example, contains some six articles of this kind, of interest to students of Somali ethnology. Somalia d'Oggi should provide a valuable means of recording local information which might otherwise never be published. It is to be hoped that the Garessa Museum may be able to make some practical contribution to research on a number of topics which urgently need investigation. Sociological and ethnographic information on the Somali populations of Southern Somalia is still very imperfect and there is need for a study of the non-Somali Bantu riverain communities which are progressively losing their identity in modern Somalia. 